\title{
Sudanese Women Lead Nonviolent Protest: An exploration on women's participation in peace, reconciliation and reconstruction
}

\author{
Rana Abdullah Issa Altom \\ Researcher, Wadmadani, Sudan \\ Corresponding author: abdallarana7@gmail.com
}

Received: 18 Jan., 2019

Revised: 13 Apr., 2019

Accepted: 29 May, 2019

\begin{abstract}
A 22-year old Sudanese engineering student, Alaa Salah has become a global icon of nonviolent protest as she stood up protesting against the authoritarian rule of former president, Omar Al Bashir. It is not just Alaa Salah but a large number of Sudanese women who are now at the forefront of peaceful protests to transform the country into a fair and just country. This chapter aims to capture the sentiments and perspectives of young Sudanese women on their pivotal role as peacebuilder.
\end{abstract}

Keywords: Women as peacebuilders, nonviolent protests, women in mediation and negotiation processes

On April 10, 2019, 22-year old Sudanese engineering student, Alaa Salah became a global icon as images of her powerful nonviolent protest in front of the military headquarters in Khartoum, Sudan was splashed across the world media. Dubbed as the Nubian queen, Alaa Salah became a symbol of the protests. Her nonviolent action has been beautifully described by Hemza Hendawi (April 10, 2019) who wrote, "In a traditional white Sudanese gown and moon-shaped golden earrings, Alaa Salah stood atop the roof of a car with her right arm raised and a finger pointing skyward. Hundreds of her fellow protesters surrounded her, their phones held high to record her. The image of the 22-year-old engineering student from Khartoum, Sudan's capital, was taken on Monday by another woman, Lana Haroun. It did not take long for it to go viral on social media and, in many ways, to become the defining image of nearly four months of street protests against the authoritarian rule of Islamist president Omar Al Bashir, demonstrations in which women have played a significant role."
It is not the first time that women in Sudan have played a central role in Sudanese society. They have always been playing an active role. According to a World Bank report, 50 percent of the Sudan's 40 million population are women and hence the efforts of women across the country for equal participation in the peace process becomes natural.

Abdulbari (April 12, 2019) discusses the historicity of women's participation in Sudanese society. He points out, "In the ancient Sudanese Nubian kingdoms, women were queens and queen mothers, and they were referred to as "Kandakat," or strongwomen. In the Darfur region, and western Sudan more broadly, women who write poems in support of virtues and traits such as bravery in times of war and generosity in times of peace have historically played significant social and political roles. This tradition has helped give strength to and inspire those leading the current uprising."

Similarly, Frietas (2016) notes, "Women in Sudan have had a big impact on conflict resolution and 
have also had a significant role in peace building, especially concerning healing, reconciliation and building bridges between divisions created by the conflict."

Further, according to scholars like Itto (2006) and Ogunasnya (2007), "Women in Sudan have contributed to peacebuilding in several ways, some of the practices used are songs, dances, peace missions and marriage. Further, the women wanted to bring in women from other communities than their own to try to build relationships and create peace and they have been especially useful in the inter-ethnic reconciliation processes."

The insights shared by Abdulbari, Frietas, Itto and Ogunasnya and the spontaneous nonviolent action by young women like Alaa Salah takes us to the important role women can play in peace and reconciliation process in Sudan and how their participation is critical for reconstruction of the conflict-ridden country. This chapter would look at these dimensions through perspectives of women who are committed to contribute towards a peaceful Sudan.

\section{The Centrality of Women's Participation in Peace and Reconciliation in Sudan}

Abdulbari (April 12, 2019) explains an important reason why large number of women took part in the protests against the ousted ruler, Omar Al Bashir. He notes, "In conflict areas outside Khartoum, the oppression of Bashir's government against women was more severe, as most of the human rights violations in these districts were committed against women and their children. They have been subjected to sexual violence by government forces or government-supported militias. They have been driven from their homes and now live in miserable conditions in camps for internally displaced people in Darfur and elsewhere. It was because of this that displaced people, the majority of whom are women, joined demonstrations in support of the uprising."

According to him, "Economic hardships may have further driven women to play a leading role in the protests because they shoulder most of the burden in maintaining the day-to-day finances of their families. They know that the economy is faltering under the weight corruption and nepotism. Whether staying at home to care for their children or working to contribute financial support to their families, women daily feel, more than men, how life is becoming difficult."

Hendawi (April 10, 2019) describing the women's participation pointed out, "Women appear to play a key role in the positive and optimistic atmosphere at the sit-in outside the military headquarters in Khartoum. Protesters sing old revolutionary and patriotic songs, play music and chant 'just fall', the slogan that morphed into a hashtag and which appears on signs, banners and walls alongside the equally popular 'freedom, peace and justice'."

In the context of Abdulbari's analysis, it can be underscored that it is not just the traditional roles that Sudanese women have played which motivated them to lead the nonviolent protests but it was also aided by the extreme conditions which women in Sudan have been facing. This fuelled their courageous and defiant participation.

For instance, Mohamed (April 23, 2019) says how increasing number of 'women activists are now demanding an equal share of seats in any civilian transitional authority and future parliament.' She talks about the strong desire of women of Sudan to have a fair and just country and why women should be at the centre of any future government.

The resilience and determination of women across Sudan to play a pivotal role in resolution of conflict through nonviolent means and ensure 'a fair and just country' is reflected by the perspectives of many young people in the country. They all want to be the catalysts to promote peace and reconciliation.

After all, it is the indomitable courage and determination of individuals to ensure sustainable peace which actually results in a culture of peace. The peace apostle, Mahatma Gandhi had rightly said, "The world will live in peace, only when the individuals composing it make up their minds to do so." Similarly, in 1969, John Lennon and Yoko Ono launched an advertising campaign in cities throughout the world, on billboards and in 
newspapers, carrying the message "War is over, if you want it."

Echoing the vision of peace apostles on the role of individuals in the evolution of a society based on ideals of peaceful coexistence, Hdeia Yousif Hassan Elhaj, a student from Wadmadani reflects, "Women are the nurturers of values like forgiveness, tolerance, cooperation, respect and acceptance of others, all of which are conducive to peace amongst and between groups." It is in this context, Hdeia argues on the need for women to play a more pro-active role in peacebuilding and reconciliation, "There is a need to involve women as major stakeholders in mechanisms for conflict management and resolution because their active participation in peacebuilding is known to modify and influence the vision of conflicting parties."

The Canadian International Development Agency (2002) describes peacebuilding as, "Peacebuilding is the effort to strengthen the prospects for internal peace and decrease the likelihood of violent conflict. The overarching goal of peace building is to enhance the indigenous capacity of a society to manage conflict without violence. Ultimately, peace building aims at building human security, a concept which includes democratic governance, human rights, rule of law, sustainable development, equitable access to resources, and environmental security."

In this context, Hdeia points out, "As women are mainly nurturers of nonviolence, love and compassion, they are best placed to enhance their capacities to manage conflict through nonviolent strategies. It is again due to these natural qualities that women can contribute to enhancement of human security not just in Sudan but globally."

As the world has seen the resilience of the women of Sudan, Azza Mohmed Ahmed, another student from Wadmadani feels women should be at the forefront of mediation and negotiation processes in order to ensure just peace. She says, "One of the advantages women have during negotiations even in most difficult situations is their ability to control their emotions. In peace processes during conflict situations, the biggest challenge is to identify root causes of communication breakdown and address issues of biases and prejudices. Women due to their inherent compassionate nature can easily overcome these biases and prejudices." Hence, women and women groups are best suited to be healers and contribute to long term reconciliation in our country, she stressed.

Referring to Azza's reflection on how breakdown in communication and issues of biases and prejudices adds to conflicts, Hadeel Yousif Hassan Elhaj, a student opines that women due to their loving nature can be more peaceful and compassionate communicator. She feels there was a need to initiate a movement for nonviolent communication led by women in Sudan. "As nonviolent communication helps us to refrain from violence in our speech, action and thoughts besides seeing others concerns empathetically, the critical situation in which Sudanese society finds itself in, we need to integrate it as our daily habits to defuse the conflict situation." Hadeel feels women-led groups should introduce nonviolent communication as a tool to resolve conflicts and use it for mediation and negotiation. She feels nonviolent communication and nonviolent conflict resolution could be integrated as compulsory education in schools and colleges.

Manasik Mohammed feels the importance of the role of women in peacebuilding and reconstruction of Sudanese society should be linked to gender equality and women's right to livelihood as citizens. As women have to bear the maximum brunt due to conflicts, when women play a pivotal role in peace processes, they are likely to ensure greater opportunities for economic and political participation, she stresses.

\section{CONCLUSION}

The chapter while looking at the historical role of Sudanese women in peace, in the backdrop of recent leadership in nonviolent protests which women took part, tried to gauge the views of women on the need for greater participation. The women, especially young women felt equal participation of women in peacebuilding was critical as it would ensure greater economic and political opportunities. 


\section{REFERENCES}

Abdulbari, Nesredeen (April 12, 2019). Why women led the uprising in Sudan; https://www.washingtonpost. com/outlook/2019/04/12/why-women-led-uprisingsudan/?noredirect=on; retrieved on July 10, 2019.

Canadian Institute Development Agency (2002). Peacebuilding Initiative Strategic Framework.

Freitas, S. 2016. 'Enhancing South Sudanese Women's Peace Building ans Reconciliation Capacity', Accord.

Hendawi, Hamza. 2019. Sudan's 'Nubian Queen' protester becomes iconic image of anti-government demonstrations; https://www.thenational.ae/world/africa/sudan-snubian-queen-protester-becomes-iconic-image-of-antigovernment-demonstrations-1.847419; retrieved on July 10, 2019.
Itto, A. 2006. 'Guests at the table? The role of women in peace processes', Conciliation resources, United Kingdom.

Mohamed, Hamza. 2019. Sudan's female protesters leading the pro-democracy movement; https://www.aljazeera. com/news/2019/04/sudan-women-protesters-leadingpro-democracy-movement-190423134521604.html; retrieved on July 10, 2019.

Ogunsanya, K. 2007. 'Women Transforming Conflicts in Africa: Descriptive Studies from Burundi, Côte D'Ivoire, Sierra Leone, South Africa and Sudan', ACCORD Occasional Paper, 2(3): 1-52. 